\title{
Correction to: Roles and action mechanisms of herbs added to the emulsion on its lipid oxidation
}

\author{
Eunok Choe $^{1}$ (D)
}

(C) The Author(s) 2020

\section{Correction to: \\ Food Sci Biotechnol (2020) 29(9):1165-1179 https://doi.org/10.1007/s10068-020-00800-z}

The article "Roles and action mechanisms of herbs added to the emulsion on its lipid oxidation", written by Eunok Choe, was originally published Online First without Open Access. After publication in volume 29, issue 9, page 1165-1179 the author decided to opt for Open Choice and to make the article an Open Access publication. Therefore, the copyright of the article has been changed to (C) The Author(s) 2020 and the article is forthwith distributed under the terms of the Creative Commons Attribution 4.0 International License (http://creativecommons.org/licen ses/by/4.0/), which permits use, duplication, adaptation, distribution and reproduction in any medium or format, as long as you give appropriate credit to the original author(s) and the source, provide a link to the Creative Commons license, and indicate if changes were made.

The original article has been corrected.

Open Access This article is licensed under a Creative Commons Attribution 4.0 International License, which permits use, sharing, adaptation, distribution and reproduction in any medium or format, as long as you give appropriate credit to the original author(s) and the source, provide a link to the Creative Commons licence, and indicate if changes were made. The images or other third party material in this article are included in the article's Creative Commons licence, unless indicated otherwise in a credit line to the material. If material is not included in the article's Creative Commons licence and your intended use is not permitted by statutory regulation or exceeds the permitted use, you will need to obtain permission directly from the copyright holder. To view a copy of this licence, visit http://creativecommons. org/licenses/by/4.0/.

The original article can be found online at https:// doi.org/10.1007/s10068-020-00800-z.

Eunok Choe

eochoe@inha.ac.kr

1 Department of Food and Nutrition, Inha University, 100 Inharo, Michuhol-gu, Incheon 22212, Republic of Korea 